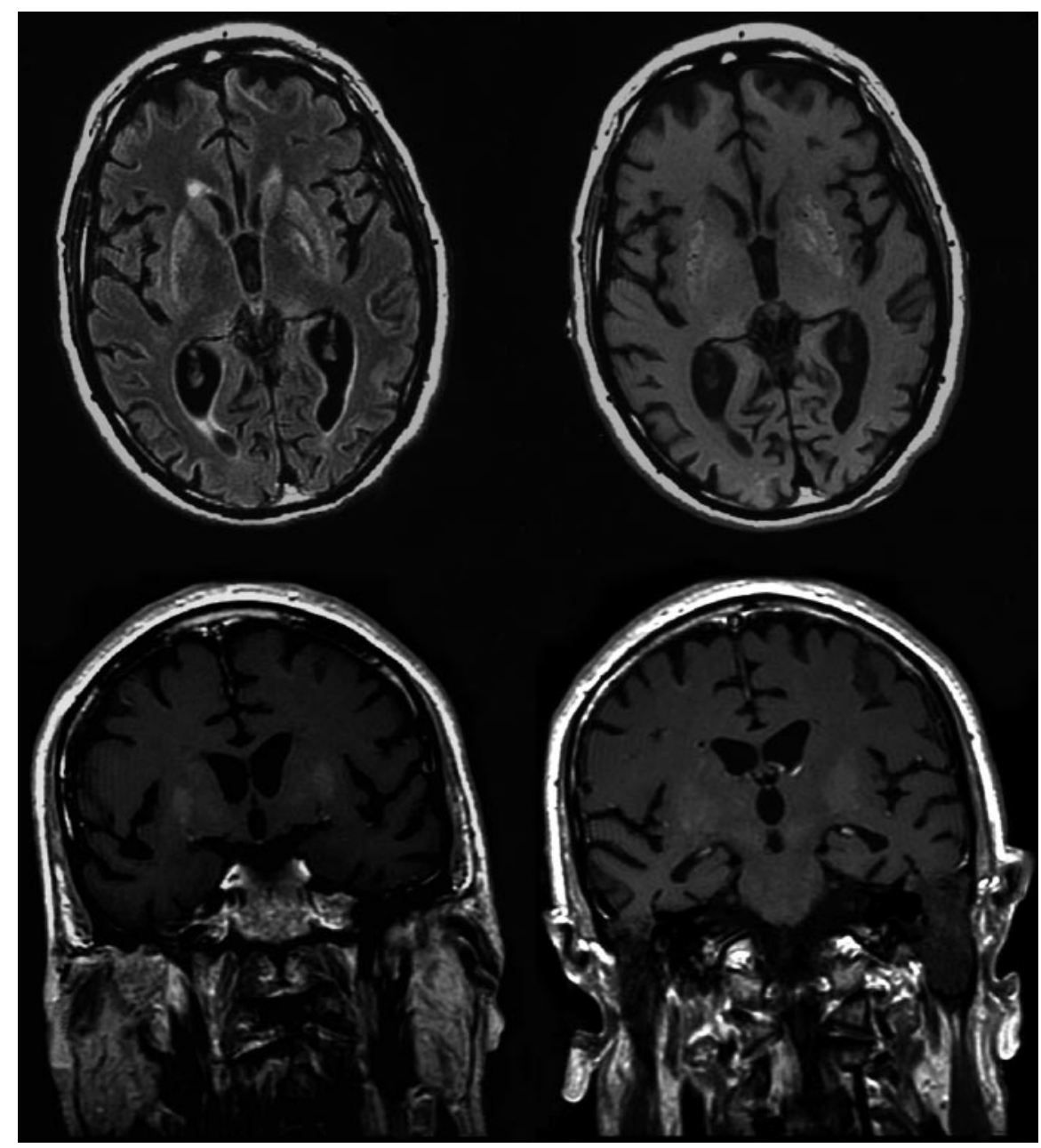

Neuro/mages

Figure. MRI of the patient's brain. Upper images: axial T2 fluid-attenuated inversion recovery (FLAIR) image (TR 8852/TE 123) at basal ganglia level and axial T1-weighted spin echo image (TR 660/TE 12) at the same level. Lower images: coronal T1-weighted spin echo images (TR 660/TE 12). There are cerebral atrophy and diffuse and extensive basal ganglia lesions involving bilaterally the nucleus caudatus, putamen, subthalamic nucleus, substantia nigra, and globus pallidus.

\section{VIDEo Bilateral chorea-ballism after cardiac arrest}

V. Di Lazzaro, MD; F. Pilato, MD; E. Saturno, MD; M. Dileone, MD; P.A. Tonali, MD; M. Antonelli, MD; M.A. Pennisi, MD; G. Bello, MD; and P. Brown, MD, Rome, Italy, and London, U.K.

Address correspondence and reprint requests to Dr. Vincenzo Di Lazzaro, Istituto di Neurologia, Università Cattolica, L.go A. Gemelli 8, 00168 Rome, Italy; e-mail: vdilazzaro@rm.unicatt.it
A 44-year-old man with a history of hypertension had an acute myocardial infarction and cardiac arrest followed by persistent deep coma. On day 4, he developed continuous, rapid, large proximal movements of the four limbs (video). The patient was initially treated with curare infusion to prevent self-injury and accidental extubation. High-dose haloperidol was started with attenuation but not suppression of involuntary movements. EEG showed alpha activity. MRI of the brain 2 months after cardiac arrest showed cerebral atrophy with bilateral massive lesions of the caudate nucleus, putamen, subthalamic nucleus substantia nigra, and globus pallidus (figure). 


\title{
Neurology
}

\author{
Bilateral chorea-ballism after cardiac arrest \\ V. Di Lazzaro, F. Pilato, E. Saturno, et al. \\ Neurology 2005;64;E20 \\ DOI 10.1212/WNL.64.6.E20
}

\section{This information is current as of March 21, 2005}

\section{Updated Information \&}

Services

Supplementary Material

Permissions \& Licensing

Reprints including high resolution figures, can be found at:

http://n.neurology.org/content/64/6/E20.full

Supplementary material can be found at:

http://n.neurology.org/content/suppl/2005/03/20/64.6.E20.DC1

http://n.neurology.org/content/supp1/2007/04/02/64.6.E20.DC2

Information about reproducing this article in parts (figures,tables) or in its entirety can be found online at:

http://www.neurology.org/about/about_the_journal\#permissions

Information about ordering reprints can be found online:

http://n.neurology.org/subscribers/advertise

Neurology ${ }^{\circledR}$ is the official journal of the American Academy of Neurology. Published continuously since 1951, it is now a weekly with 48 issues per year. Copyright . All rights reserved. Print ISSN: 0028-3878. Online ISSN: 1526-632X.

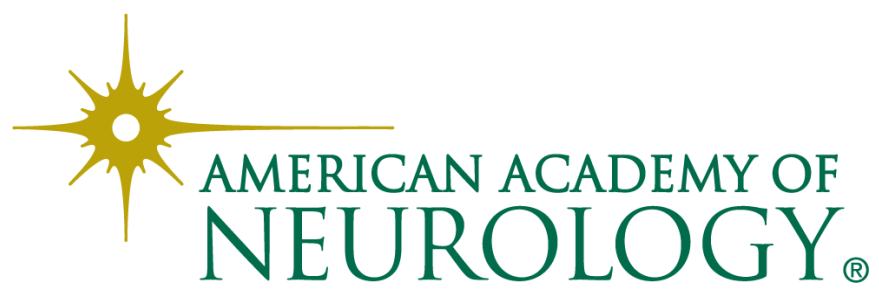

